\title{
Regulatory Autonomy under the WTO Agreement on Sanitary and Phytosanitary Measures: Implications of Korea-Import Bans, and Testing and Certification Requirements for Radionuclides - ERRATUM
}

\author{
Yong-Shik Lee
}

doi:10.1017/S147474562100001X, Published by Cambridge University Press, 14 April 2021.

Keywords: World Trade Organization; SPS agreement; appropriate level of protection; qualitative requirements; rational basis test

In this article the title was incorrectly typeset as 'Regulatory Autonomy under the WTO Agreement on Sanitary and Phytosanitary Agreement: Implications of Korea-Import Bans, and Testing and Certification Requirements for Radionuclides' on the cover, in the internal contents list, on page 321 in the article title, on line four of the abstract and on page 342 in the 'Cite this article' section at the end of the text.

The publisher apologises for this error.

\section{Reference}

Lee, Y-S. (2021) 'Regulatory Autonomy under the WTO Agreement on Sanitary and Phytosanitary Measures: Implications of Korea-Import Bans, and Testing and Certification Requirements for Radionuclides', World Trade Review 321-342. https://doi.org/10.1017/S147474562100001X

Cite this article: Lee Y-S (2021). Regulatory Autonomy under the WTO Agreement on Sanitary and Phytosanitary Measures: Implications of Korea - Import Bans, and Testing and Certification Requirements for Radionuclides - ERRATUM. World Trade Review 20, 728. https://doi.org/10.1017/S1474745621000380

(c) The Author(s), 2021. Published by Cambridge University Press 